\title{
SYNTHESIS, CHARACTERIZATION AND ANTIBACTERIAL ACTIVITY OF COBALT(III) COMPLEX WITH PHENANTHROLINE AND MALTOSE
}

\author{
JOSÉ PARADA ${ }^{1 *}$, ANA MARÍA ATRIA ${ }^{1}$, GUILLERMO WIESE ${ }^{2}$, ELIZABETH RIVAS $^{2}$, GINO CORSINI ${ }^{2}$ \\ ${ }^{1}$ Facultad de Ciencias Quimicas y Farmacéuticas, Universidad de Chile, Santiago, Chile. \\ ${ }^{2}$ Centro de Investigación Biomédica, Universidad Autónoma de Chile. Santiago. Chile
}

\begin{abstract}

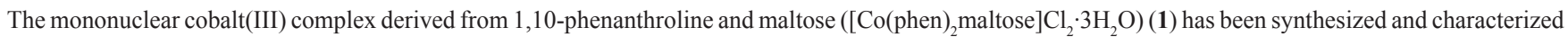
in aqueous solution. Its characterization was based on its optical and spectroscopic properties.

The antimicrobial activity of this complex was screened in vitro against the microorganisms Escherichia coli DH5 $\alpha$, Salmonella enterica sv Enteritidis ISP/953, Klebsiella pneumoniae RYC492, Pseudomonas aeruginosa PAO1, Enterococcus faecalis ATCC 29212, Bacillus cereus GCA234, Micrococcus sp. Staphylococcus aureus ATCC25923.

Complex (1) showed antibacterial activity with a bacteriostatic effect over Gram positive and negative bacteria. The cytotoxicity of complex (1) was tested in vitro on human embryonic kidney cells.
\end{abstract}

Keywords: Carbohydrate-cobalt(III) complexes; circular dichroism; antibacterial activity.

\section{INTRODUCTION}

Transition metal complexes are of interest since they display a wide variety of application in fields ranging from materials science and catalysis to biological activity [1]

From the biological point of view, several studies have shown that the complexes may have antibacterial, antifungal and antitumor activity [2].

The biological activity of metal complexes is highly dependent on the nature of the metal ions and the donor sequence of the ligands because different ligands exhibit different biological properties [3].

An interesting group of ligands are the carbohydrates [4], whose complexes have shown significant antimicrobial activity against Gram-positive and Gramnegative bacterial strains as well as a few fungal strains [5]. Poller and Parkin reported the synthesis of organometallic derivatives of sucrose (lead, tin and germanium). In that study organotin was found to exhibit higher biocidal activities than would be expected from the tin content [6].

A few sugar-cobalt complexes with antibacterial activity have been reported. An important example is grafted PVA polymer with a derivative of erythro-ascorbic acid (pentulosono-lactone-2,3-enedianisoate) reported by Salih et al. It was evaluated for antimicrobial properties against four pathogenic bacteria (Escherichia coli, Klebsiella pneumonae, Staphylococcus aureus, Staphylococcus albus) and fungi (Aspergillus niger, yeast). This cobalt complex showed good activity against the various microbial isolates [7].

1,10-Phenanthroline is also one of the biologically important ligands, and several studies show that this ligand and a number of its complexes are effective against various strains of microorganisms. Examples are the complexes $\left.\left[\mathrm{Cu}(\text { phen })_{2} \mathrm{mal}\right)\right] \cdot 2 \mathrm{H}_{2} \mathrm{O}$ and $\left[\mathrm{Ag}_{2}(\text { phen })_{2}(\mathrm{mal})\right] \cdot 2 \mathrm{H}_{2} \mathrm{O}$ (phen $=$ 1,10-phenanthroline, malH $_{2}=$ malonic acid) reported by B. Coyle et al. which inhibit the growth of Candida albicans [8].

Here the synthesis of the mixed ligand cobalt complex [Co(phen), maltose] $\mathrm{Cl}_{2} \cdot 3 \mathrm{H}_{2} \mathrm{O}(\mathbf{1})$, as well as its spectral features and optical activity are reported.

UV-visible absorption spectroscopy and circular dichroism spectroscopy allow us to assign a $\Delta$ configuration to complex (1).

The complex was also screened for antibacterial activity against Gram positive and Gram-negative bacteria. We determined the antibacterial effects and evaluated their cytotoxic effect on human cells.

\section{EXPERIMENTAL}

\subsection{Materials and instruments}

All reagents and solvents employed were commercially available and were used as received without further purification.

The cobalt content of the complexes in the solutions as well as in the solid compounds was determined by atomic absorption spectroscopy with a Perkin Elmer 1100B spectrophotometer. Absorption spectra were recorded on a Unicam UV3 instrument. The circular dichroism (CD) spectra were monitored with a Yobin-Yvon CD 6 spectrometer. The elemental analyses were performed by Analyses Elemental CE Instruments EA 1108. The infrared spectrum $\left(4000-600 \mathrm{~cm}^{-1}\right)$ was recorded using $\mathrm{KBr}$ pellets on a Perkin Elmer FT-IR C 97945 spectrometer. ${ }^{1} \mathrm{H}-\mathrm{NMR}$ measurements were performed in DMSO- $\mathrm{d}_{6}$ solution on a Bruker DXR 300 spectrometer $(300 \mathrm{MHz})$.

2.2 Synthesis of the complex

Complex (1) was prepared by a procedure similar to that for the preparation of compounds $\left[\mathrm{Co}(\text { phen })_{2} \mathrm{~L}\right]^{2+}(\mathrm{L}=$ arabinose $(2)$ and galactose (3)) reported by Parada et al. An aqueous solution of $\left[\mathrm{Co}(\mathrm{phen})_{2} \mathrm{Cl}_{2}\right] \mathrm{Cl}\left(10^{-2} \mathrm{M}\right)$ was mixed with a two-fold molar excess of maltose and the $\mathrm{pH}_{2}$ was adjusted to 9.0 by addition of $\mathrm{NaOH}[9]$.

The complex was separated by chromatography on a Sephadex C25 column by elution with $0.1 \mathrm{M} \mathrm{NaCl}$.

The eluate was evaporated to dryness under reduced pressure, followed by extraction with $\mathrm{EtOH}$ and $\mathrm{MeOH}$ to remove the $\mathrm{NaCl}$. Anal. Calcd for $\mathrm{CoC}_{36} \mathrm{H}_{43} \mathrm{~N}_{4} \mathrm{O}_{14} \mathrm{Cl}_{2}$ : Co, 6.65; C, 48.82; H, 4.85; N, 6.33, Found: Co, 7.15; C, $48.32 ; \mathrm{H}, 4.69 ; \mathrm{N}, 5.87$.

2.3. Antimicrobial activity measurements.

All antimicrobial activity assays were performed in triplicate and confirmed by three separate experiments. The antimicrobial activity was investigated against some Gram-positive (Enterococcus feacalis ATCC29212, Bacillus cereus GCA234, Micrococcus sp. and Staphylococcus aureus ATCC25923) and Gram-negative bacteria (Escherichia coli DH5a, Salmonella enterica sv Enteritidis ISP/953, Klebsiella pneumoniae RYC492 and Pseudomonas aeruginosa PAO1).)

Bacteria were grown in Mueller Hinton agar (Difco) as well as Mueller Hinton broth (Difco) for 16 to $24 \mathrm{~h}$ at $37^{\circ} \mathrm{C}$ in an incubator.

The in vitro antibacterial activity of the complexes was tested using the paper disk diffusion method [12] and the minimal inhibitory concentration (MIC) was determined as the lowest concentrations of drug in the medium at which no microbial growth was visible [13].

2.4 Antibacterial effect

The in vitro antibacterial effect of the complexes was tested using a modified chromogenic plate test assay [14] E. coli HB101, which contains a chromosomal IPTG-inducible $\beta$-galactosidase gene. The chromogenic agar plates were prepared as follows: First, an inoculum with this strain was grown overnight in $2 \mathrm{~mL}$ of Mueller Hinton medium, at $37^{\circ} \mathrm{C}$ with shaking. Then, a top agar-incubation mix containing $5 \mathrm{~mL}$ of $0.8 \%$ agar previously melted at 45 ${ }^{\circ} \mathrm{C}$ containing $0.1 \mathrm{~mL}$ of the bacterial cell inoculum, $0.01 \mathrm{~mL}$ of $1 \mathrm{mM}$ IPTG, and $0.1 \mathrm{~mL}$ of X-Gal $50 \mathrm{mg} / \mathrm{mL}$ was vortex-mixed and carefully overlaid on Mueller Hinton agar plates prepared the day before. The disks containing the appropriate concentration of complex or antibiotic were deposited on the chromogenic agar plates. The plates were then incubated at $37^{\circ} \mathrm{C}$ for $12-24$ 
$\mathrm{h}$, the inhibition zones were visually inspected for color formation along de edges of the disks, and the plates were photographed. Only compounds causing cellular lysis produce a blue-colored edge at the inhibition zone.

\subsection{Cytotoxic effect}

The cytotoxicity of the complexes was tested in vitro on human cells using microplate cultures of human kidney embryonic cells (HEK293 cells) grown in DMEM medium plus $10 \%$ bovine fetal serum. The number of dead cells was determined by an MTT cell proliferation assay after $24 \mathrm{~h}$ of incubation with the complexes. [15] This method is a colorimetric assay system which measures the reduction of a tetrazolium component (MTT) to an insoluble formazan product by the mitochondria of viable cells. The amount of color produced is directly proportional to the number of viable cells.

\section{RESULTS AND DISCUSSION}

3.1 Spectroscopic characterization of $\left[\mathrm{Co}(\text { phen })_{2}\right.$ maltose $] \mathrm{Cl}_{2} \cdot 3 \mathrm{H}_{2} \mathrm{O}$ complex (1)

The IR spectrum of the complex (1) showed characteristic bands of 1,10-phenanthroline and maltose ligands.

The spectrum shows a broad absorption band at $3462 \mathrm{~cm}^{-1}$ that can be associated with $v(\mathrm{O}-\mathrm{H})$ of the maltose, and weak bands at 3052 and $2930 \mathrm{~cm}^{-1}$ that can be assigned to $\mathrm{C}-\mathrm{H}$ stretching vibrations of maltose and phenanthroline, respectively. In the $1600-1400 \mathrm{~cm}^{-1}$ region the spectrum shows bands corresponding to $v(\mathrm{C}=\mathrm{C}, \mathrm{C}=\mathrm{N})$ of the phenanthroline ligand. Bands between $1342-1316 \mathrm{~cm}^{-1}$ involve $\mathrm{O}-\mathrm{H}, \mathrm{CH}, \mathrm{CH}_{2}$ bending modes of the maltose .The peak at $1146 \mathrm{~cm}^{-1}$ have been assigned to $\mathrm{C}-\mathrm{C}$ in-plane bending and the peaks at 1105 and $1195 \mathrm{~cm}^{-1}$ have been identified as bands associated with C-O-C bending. The $v \mathrm{H}$ (in plane) and $\delta \mathrm{H}$ (out plane) vibration of the phenanthroline are located in the $1038-700 \mathrm{~cm}^{-1}$ region

The ${ }^{1} \mathrm{H}-\mathrm{NMR}$ spectrum of the complex reveals the resonance signals of the aliphatic hydrogen of the maltose $(\delta 3.0-5.0 \mathrm{ppm})$ and aromatic hydrogen of the phenanthroline $(\delta 7.6-9.1 \mathrm{ppm})$ to be well separated. The relation between two different signals is 1:3 which is in agreement with the proposed structure of the complex.

An absorption band at $272 \mathrm{~nm}$ is seen in the UV spectrum. The band is associated with $\mathrm{p}$ transitions of the 1,10-phenanthroline ligands. In this region the CD spectrum presents two bands of opposite signs which appear at 266 $(+)$ and $280(-) \mathrm{nm}$. The signs sequence is related to the $\Delta$ configuration of the chelate rings (excitonic effect) [10].

The complex showed a second positive $\mathrm{CD}$ signal under a shoulder in the UV region (322 nm), related to the $\pi \rightarrow \pi^{*}$ transition along the short axis of the phenanthroline rings.

In the visible region, the complex exhibited an absorption band at $486 \mathrm{~nm}$ corresponding to the ${ }^{1} \mathrm{~A}_{1 \mathrm{~g}} \rightarrow{ }^{1} \mathrm{~T}_{1 \mathrm{~g}}$ transition. In the $\mathrm{CD}$ spectra two signals $(+)$ and (-) can be detected, which are correlated with the $\Delta$ configuration [11]. The $\mathrm{CD}$ spectra also showed a third signal (-) at $358 \mathrm{~nm}$ than can be assigned to the ${ }^{1} \mathrm{~T}_{2 \mathrm{~g}}$ state in octahedral symmetry.

The UV-VIS absorption and CD spectra of complex (1) are consistent with those reported earlier for $\left[\mathrm{Co}(\mathrm{phen})_{2} \mathrm{~L}\right] \mathrm{Cl}_{2}$, where $\mathrm{L}=$ arabinose for (2) and galactose for (3) as seen in Figures 1 and 2.

\subsection{Biological studies}

The in vitro antibacterial activity of complex (1) was evaluated against representative Gram positive and Gram negative bacteria. Its activity was compared with that presented by the homologous complexes with arabinose (2) and galactose (3) as ligands. The results of antibacterial activity and minimum inhibitory concentration (MIC) are reported in Tables 1 and 2, respectively.

Table 1 shows the antibacterial effect of the compounds using the paper disk diffusion method. The galactose complex (3) did not show any antibacterial effect on the tested bacteria, while the maltose complex (1) and the arabinose complex (2) display activity against Escherichia coli, Salmonella Enteritidis, Klebsiella pneumonia, Bacillus cereus and Micrococcus sp. bacteria. They did not show activity against Pseudomonas aeruginosa, Enterococcus faecalis and Staphylococcus aureus.
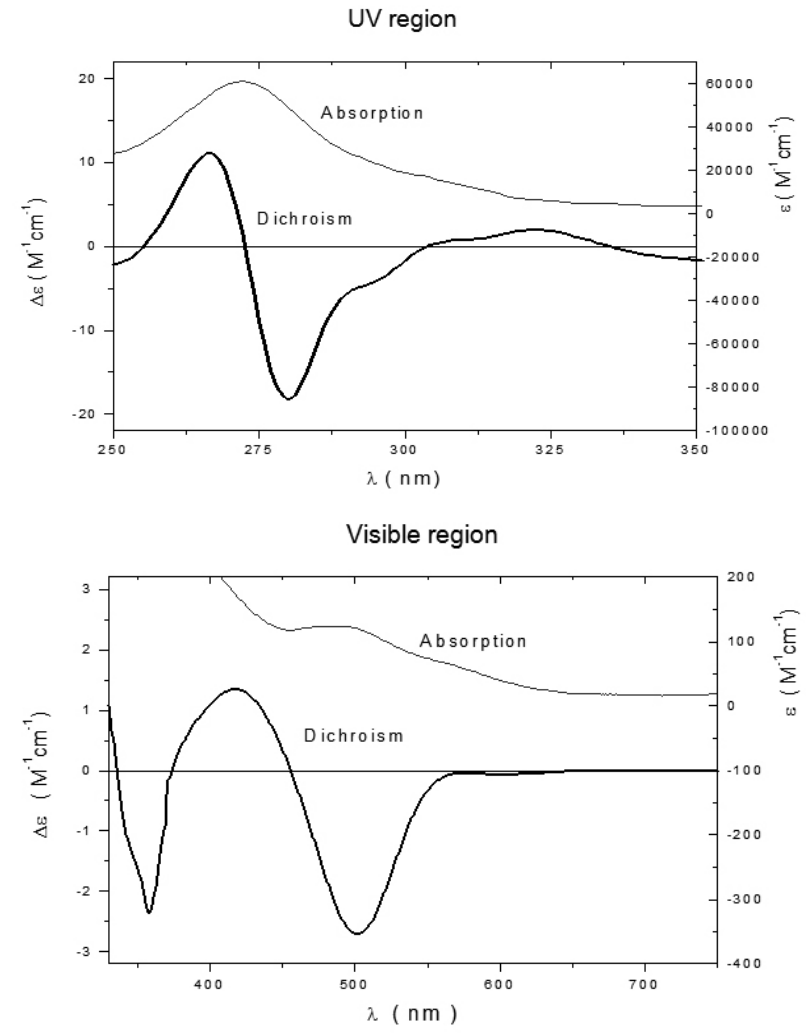

Figure 1. Absorption and circular dichroism (CD) spectra of $\left[\mathrm{Co}(\text { phen })_{2} \text { maltose }\right]^{2+}$ complex (1).
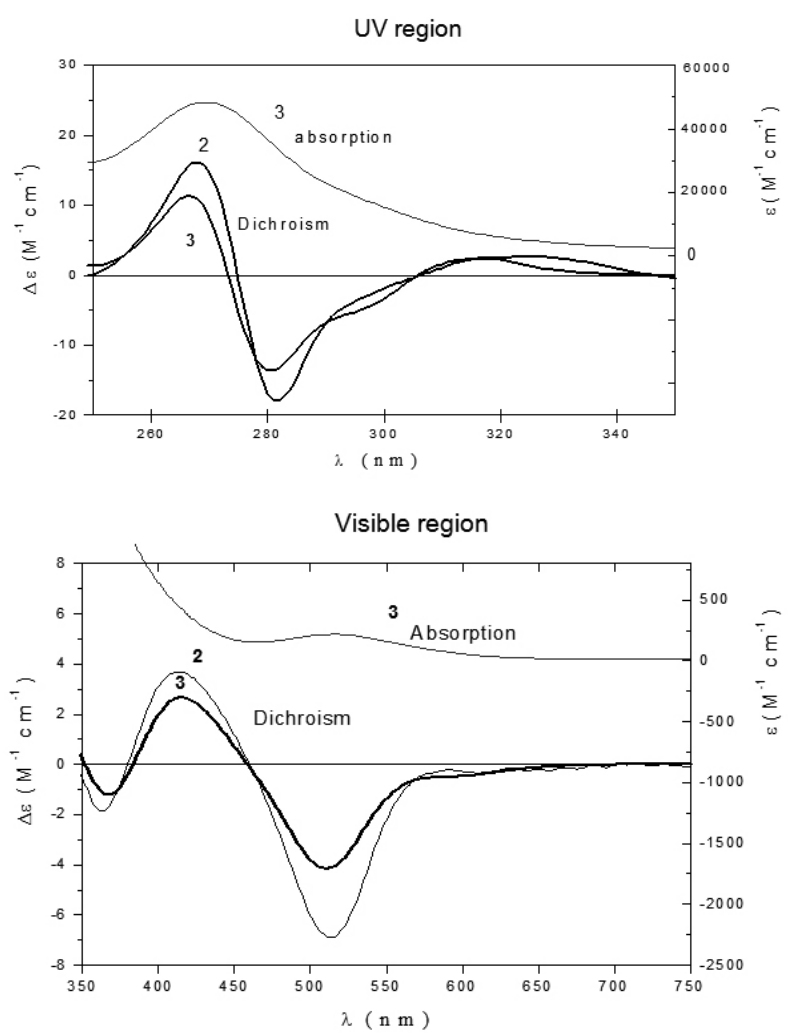

Figure 2. Absorption and circular dichroism (CD) spectra of $\left[\mathrm{Co}(\text { phen })_{2} \text { arabinose }\right]^{2+}(\mathbf{2})$ and $\left[\mathrm{Co}(\text { phen })_{2} \text { arabinose }\right]^{2+}$ complexes (3). 
Table 1. Qualitative antibacterial activity of $\left[\mathrm{Co}(\text { phen })_{2} \text { maltose }\right]^{2+}(\mathbf{1}),\left[\mathrm{Co}(\text { phen })_{2} \text { arabinose }\right]^{2+}(\mathbf{2})$, and $\left[\mathrm{Co}(\text { phen })_{2} \text { galactose }\right]^{2+}(\mathbf{3})$ complexes.

\begin{tabular}{|l|c|c|c|c|c|}
\hline \multirow{2}{*}{ Bacteria } & \multicolumn{5}{|c|}{ Growth inhibition zone (mm)* } \\
\cline { 2 - 6 } & Co-MAL (1) & Co-ARA (2) & Co-GAL (3) & KAN & ZOX \\
\hline Escherichia coli DH5 $\alpha$ & $14.1 \pm 1.1$ & $17.0 \pm 0.8$ & $\mathrm{R}$ & $21.4 \pm 0.4$ & ND \\
\hline Salmonella Enteritidis & $13.5 \pm 0.9$ & $15.6 \pm 1.0$ & $\mathrm{R}$ & $23.4 \pm 0.6$ & $\mathrm{ND}$ \\
\hline Klebsiella pneumoniae & $19.5 \pm 1.0$ & $20.0 \pm 0.5$ & $\mathrm{R}$ & $\mathrm{R}$ & $\mathrm{ND}$ \\
\hline Pseudomonas aeruginosa & $\mathrm{R}$ & $\mathrm{R}$ & $\mathrm{R}$ & $\mathrm{R}$ & $\mathrm{N}$ \\
\hline & & & & $\mathrm{R}$ & $\mathrm{N}$ \\
\hline Enterococcus feacalis & $\mathrm{R}$ & $\mathrm{R}$ & $\mathrm{R}$ & $\mathrm{R}$ & $\mathrm{N}$ \\
\hline Bacillus cereus & $14.4 \pm 0.3$ & $15.4 \pm 0.7$ & $\mathrm{R}$ & $22.1 \pm 0.6$ & $\mathrm{ND}$ \\
\hline Micrococcus sp. & $15.2 \pm 0.8$ & $14.3 \pm 1.1$ & $\mathrm{R}$ & $18.8 \pm 0.8$ & $34.7 \pm 0.7$ \\
\hline Staphylococcus aureus & $\mathrm{R}$ & $\mathrm{R}$ & $\mathrm{R}$ & $\mathrm{ND}$ & \\
\hline
\end{tabular}

* Disc with $400 \mu \mathrm{g}$ of compound. Number of assays $=3$. Co-MAL: $\left[\mathrm{Co}(\mathrm{phen})_{2} \text { maltose }\right]^{2+}$,

Co-ARA: $\left[\mathrm{Co}(\text { phen })_{2} \text { arabinose }\right]^{2+}$, Co-GAL: $\left[\mathrm{Co}\left(\text { phen) }{ }_{2} \text { galactose }\right]^{2+}\right.$, KAN: Kanamycin (disk with $30 \mu \mathrm{g}$ ),

ZOX: Ceftizoxime (disk with $30 \mu \mathrm{g}$ ). $\mathrm{R}=$ resistant, $\mathrm{ND}=$ not determined.

Table 2. Antibacterial activity by minimal inhibition concentration (MIC) of $\left[\mathrm{Co}(\mathrm{phen})_{2} \text { maltose }\right]^{2+}$ and $\left[\mathrm{Co}(\mathrm{phen})_{2} \text { arabinose }\right]^{2+}$ complexes.

\begin{tabular}{|c|c|c|}
\hline \multirow[b]{2}{*}{ Bacteria } & \multicolumn{2}{|c|}{ MIC $(\mu \mathrm{g} / \mathrm{mL})^{*}$} \\
\hline & $\begin{array}{c}{\left[\mathrm{Co}\left(\text { phen) }{ }_{\text {(1) }} \text { maltose }\right]^{2+}\right.} \\
\text { (1) }\end{array}$ & $\begin{array}{c}{\left[\mathrm{Co}(\text { phen })_{2} \text { arabinose }\right]^{2+}} \\
\text { (2) }\end{array}$ \\
\hline Escherichia coli & 40 & 40 \\
\hline Salmonella Enteritidis & 40 & 60 \\
\hline Klebsiella pneumoniae & 60 & 60 \\
\hline Bacillus cereus & 60 & 80 \\
\hline Micrococcus sp. & 60 & 80 \\
\hline
\end{tabular}

$*$ Number of assays $=3$.

Both complexes showed moderate antibacterial activity when compared with the standard drug kanamycin. On the other hand, these complexes exhibited antibacterial activity against Klebsiella pneumonia compared to the reference drug.

Diffusion disks assay showed no difference in the antibacterial activity of complexes (1) and (2), which showed bacterial growth inhibition with MIC values ranging between $40-60 \mu \mathrm{g} / \mathrm{mL}$ and $40-80 \mu \mathrm{g} / \mathrm{mL}$, respectively (Table 2).

We used a plate assay to distinguish bactericidal from bacteriostatic action modes of the antimicrobial complexes $[16,17]$. This method was based on the use of $\beta$-galactosidase as an appropriate marker of cellular lysis. If lysis occurs, the enzyme activity is released outside the bacterium and detected on the plate. When the enzyme reaches the agar medium, it hydrolyzes 5-bromo-4-chloro3 -indolyl- $\beta$-D-galactoside (X-Gal), a chromogenic compound included in the agar. After overnight incubation, X-Gal forms a blue circle staining the edge of the inhibition zone produced by the antibiotic application. Only compounds causing cellular lysis or membrane damage produce a blue-colored edge at the inhibition zone.

The assay showed that complexes (1) and (2) present bacteriostatic activity because they do not produce a blue circle staining the edge of the inhibition zone (Fig. 3). Ceftizoxime and chloramphenicol were used as bactericidal and bacteriostatic control agents, respectively.

In order to evaluate the ability of the compounds to damage eukaryotic cells, the in vitro cytotoxic effect of these complexes was tested on human embryonic kidney cells (Fig. 4).

Analysis of cytotoxicity curves reveals that the complexes studied are not toxic to human cell at MIC concentration. At $200 \mu \mathrm{g} / \mathrm{mL}$ concentrations there was about $80 \%$ survival of human cells, which is four times above the average of the MIC value for each compound. The results also show IC $\mathrm{IC}_{50}$ values for complexes (1) and (2) of $870 \mu \mathrm{g} / \mathrm{mL}$ and $>1000 \mu \mathrm{g} / \mathrm{mL}$, respectively. All this indicates that both complexes does not have an in vitro cytotoxic effect at concentrations of biological interest (4 times the MIC).

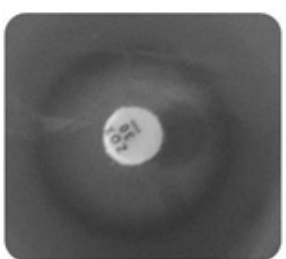

Ceftizoxime

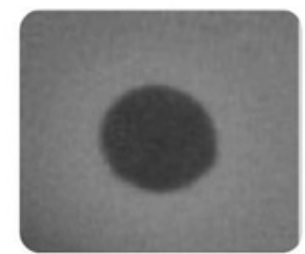

$[\text { Co(phen })_{2}$ maltose $]^{2+}$

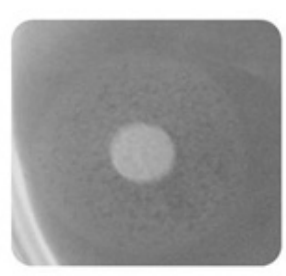

Chloramphenicol

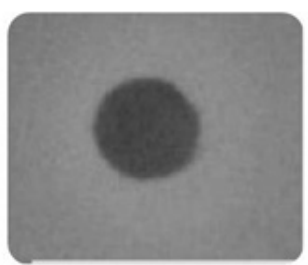

$[\text { Co(phen })_{2}$ D-arabinose $]^{2+}$
Figure 3. Plate assay showing bacteriostatic or bacteriolytic effect of complexes (1) and (2) over Gram-negative bacteria Escherichia coli BL21 (DE3). Used in assay disk with $400 \mu \mathrm{g}$ of analyzed complex. Disc of ceftizoxime $(30 \mu \mathrm{g} / \mathrm{disk})$ and chloramphenicol $(30 \mu \mathrm{g} / \mathrm{disk})$ were used as bacteriostatic and bacteriolytic control respectively. 
A

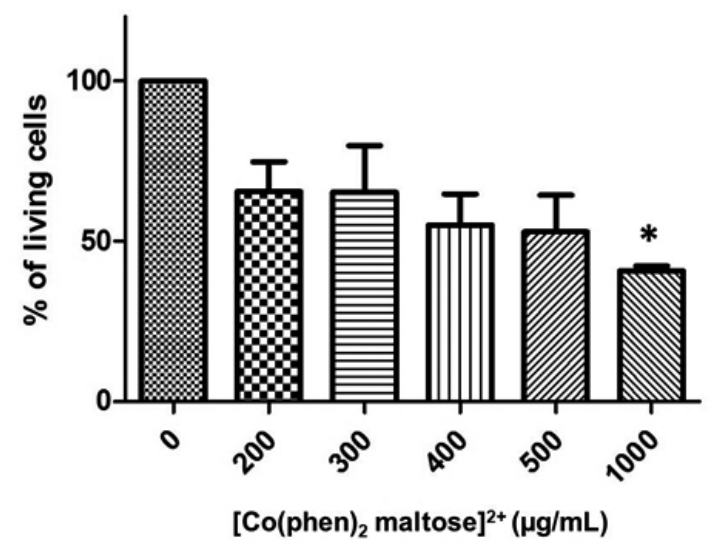

B

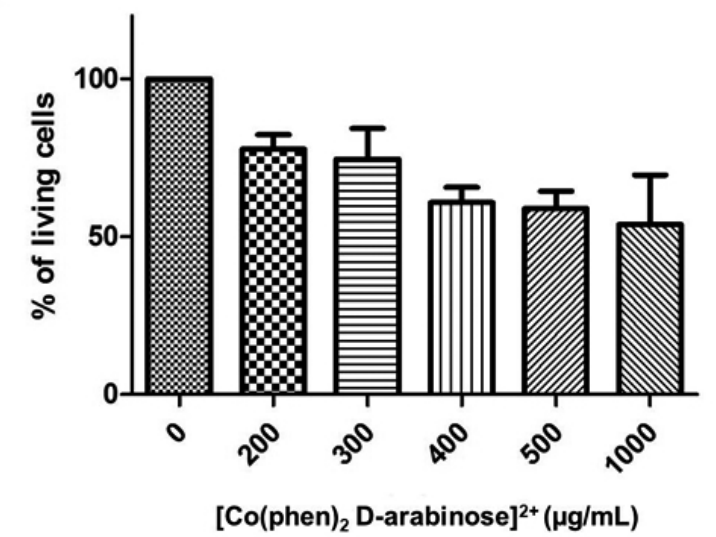

Figure 4. In vitro cytotoxicity effect of complexes on human cell (HEK293 cell).

\section{CONCLUSIONS}

Circular dichroism studies and UV-visible spectroscopy allowed to assign a delta configuration to complex (1). This complex showed antibacterial activity with a bacteriostatic effect over Gram-positive and Gram-negative bacteria, and the cytotoxicity test showed that the cobalt compound had low toxicity.

\section{ACKNOWLEDGMENTS}

Support under FONDECYT Project 1120125 is gratefully acknowledged.

\section{REFERENCES}

[1] K. D. Mjos, C. Orvig, Chem. Rev. 114, 4540 (2014).

[2] B. S. Sekhon, J. Pharm. Educ. Res. 2, 1, (2011).

[3] C. X. Zhang, S. J. Lippard, Curr. Opin. Chem. Biol. 7, 481, (2003).

[4] ) D. M. Whitfield, S. Stojkovski and B. Sarkar, Coord. Chem. Rev. 122, 171, (1993); b) S. Yano, Coord. Chem. Rev. 92, 113, (1988); c) B. Gyurcsik and L. Nagy, Coord. Chem. Rev. 203, 81, (2000).

[5] H. R. Appelt, J. S. Oliveira, R. C. V. Santos, O.E.D. Rodrigues, M. Z. Santos, E. F. Heck, and L. C. Rosa, Int. J.Carbohydr. Chem. 2013, (2013). http://dx.doi.org/10.1155/2013/320892 Article ID 320892,

[6] (a) A. Parkin, R. C. Poller, Int. Pest. Control, 19, 5, (1977), b) R. C. Poller, A. Parkin, ACS Symp. Ser. 41, 145, (1977).

[7] T. M. Salih, R. M. Rumez, M. A. Younus, B. I. Khalil and B. W. Khammas, Jolst. 1, 51, (2013). doi: 10.12720/jolst.

[8] B. Coyle, K. Kavanagh, M. McCann, M. Devereux, M. Geraghty, Bio Metals 16, 321, (2003)

[9] a) J. Parada, S. Bunel, C. Ibarra, G. Larrazábal, E. Moraga, Carbohydr.
Res. 329, 195, (2000); b) J. Parada, S. Bunel, C. Ibarra, G. Larrazábal, E. Moraga, N.D. Gillitt, C.A. Bunton, Carbohydr. Res. 333, 185, (2001); c) J. Parada, S. Bunel, C. Ibarra, G. arrazábal, E. Moraga, N. Gillitt, C.A. Bunton, Polyhedron 21, 2215, (2002); d) J. Parada, G. Larrazábal, Polyhedron 23, 1341, (2004).

[10] a) C. J. Hawkins, Absolute Configuration of Metal Complexes, Wiley, New York, 1971. b) K. Nakanishi, N. Berova and R. W. Woody (Eds.), Circular Dichroism, Principles and Applications, VCH, Cambridge, 1994.

[11] a) I. Tinico, Adv. Chem. Phys. 4, 113, (1962); b) F.S. Richardson, J. Chem. Phys. 54, 2453, (1971).

[12] K. L. Kwaniewska, Bull. Environ. Contam. Toxicol, 27, (1981).

[13] National Committee for Clinical Laboratory Standards; Methods for Dilution Antimicrobial Susceptibility Tests for Bacteria That Grow Aerobically, Fifth Edition: Approved Standard M7-A5. NCCLS, Wayne, PA, USA, 2000.

[14] G. Mardones, A. Venegas, J. Microbiol. Meth., 40, 199, (2000).

[15] S. Maher, S. McClean, Biochem. Pharmacol. 71, 1289, (2006).

[16] P. Cortés-Cortés, A. M. Atria, M. Contreras, O. Peña, K. Fernández, G. Corsin, J. Chil. Chem. Soc. 53, 1527, (2008).

[17] A. M. Atria, P. Cortés-Cortés, M.T. Garland, R. Baggio, K. Morales, M. Soto, G. Corsini, J. Chil. Chem. Soc. 56, 786, (2011). 